\title{
The Causation of Protestant Reformation: Lessons of History
}

\author{
Etim E. Okon Ph.D \\ Senior Lecturer, Department of Religious and Cultural Studies, University Of Calabar, CRS, Nigeria
}

\begin{abstract}
To whom do we attribute the negative consequences of the Reformation to? Was the Reformation the outcome of Luther's rebellious spirit, or a culmination of multiplicity of factors? Who was Luther in the medieval church? These are some of the puzzling questions this paper has attempted to answer with historical insight. The study shows that the medieval church was ripe for reforms and that calls for reforms antedates the protest of Luther and other reformers in the sixteenth century. The research leads contemporary ecclesiastical historians into a multifaceted historical analysis on the causation and political forces that made the Reformation inevitable.

Keywords: Ecclesiastical history, Reformation, Causation, Protestantism, Catholicism
\end{abstract}

\section{Introduction}

Ecclesiastical historians are often confused in answering the question "What caused the Reformation?" Some scholars conclude "The church was corrupt". To others, especially within the Roman Catholic Church, Martin Luther was arrogant and rebellious. Luther himself blamed the events to the sinful and depraved nature of papal leadership of that time. It was his considered opinion that the pope was corrupt, immoral and oppressive. The Roman Curia and most of their supporters viewed Luther as a troublemaker who exalted his personal opinions over and above the collective wisdom of the ages. Luther's exit from the Catholic Church was interpreted as his inability to control his passion. His marriage with a former nun was seen as a proof of his psychological and emotional instability. Carl Gustavson (1955: 54) has said that in the heat of conflict, people are always tempted to ascribe malignant characters and purposes to their enemies and that even when there may be some element of truth there is always the danger and temptation to either oversimplify, or overemphasize the facts.

Gustavson went on to say that leaders of popular social movements cannot ignore the prevailing ideas, values and pressure groups that surround them: "No man in a public movement is a free agent or can act entirely according to his own free will. Although he seeks certain objectives and will strive toward them, he must take into consideration other forces or speedily come to an impasse" (1955:54). The argument of Gustavson is plain and simple. It is poor historical thinking to attribute a major and complex historical development to one single cause. It is a typical rudimentary historical thinking to overrate one single social force at the expense of other factors. Gustavson elucidates further: "Very often the immediate cause whether seen in terms of a person, or of an event receives greater emphasis than it deserves... The more remote causes in history establish the particular situation which makes the whole historical sequence possible. No single cause ever adequately explains a historical episode" (1955:55).

\section{The Religious Causes of the Reformation}

To Luther, and the majority of his early followers, Reformation as a movement was a rebellion against abuses in the Catholic Church. It was reported that some clergymen obtained their positions through irregular and fraudulent means. Some clergymen led immoral and scandalous lives. Commenting on some of the abuses, Edward Burns (1973:399) notes that while some of the popes and bishops were living in opulence, the lower cadre of the priesthood occasionally sought to survive through... "the incomes from their parishes by keeping taverns, gaming houses, or other establishments for profit. Not only did some monks habitually ignore their vows of chastity, but a few indifferent members of the clergy surmounted the hardships of the rule of celibacy by keeping mistresses".

It is on record that Pope Innocent VIII, who ruled the Roman Catholic Church for twenty-five years before the Reformation, had eight illegitimate children, some born before his election by the College of Cardinals (Burns 1973:399-400). There were also the scandalous practices of selling ecclesiastical offices to the highest bidder. Pope Leo X generated more than a million dollars in one year from the sale of more than 2000 ecclesiastical offices. Burns (1973:400) observes that: "This abuse was rendered more serious by the fact that the men who bought these positions were under a strong temptation to make up for their investment by levying high fees for their services". 
Another abuse that was condoned and legitimated was the sale of dispensations. This was an ecclesiastical graft which granted immunity to the holder from the law of the church, or from some vow previously taken. Closer to the Reformation, the dispensations that were commonly sold were exemptions from fasting and from the marriage laws of the church, "first cousins would be permitted to marry for the payment of a fee of one ducat" (Burns 1973: 400). There were also abuses connected with the veneration of sacred relics. For centuries; the veneration of sacred relics was an important element in Catholic spirituality. The prevailing doctrinal speculation was that objects use by Jesus, the Virgin Mary, or the saints possessed mystical protective and healing virtues for whoever touched them. "According to Erasmus, the churches of Europe contained enough wood of the cross to build a ship. No fewer than five ship bones of the ass on which Jesus rode to Jerusalem were on exhibition in different places, to say nothing of twelve heads of John the Baptist" (Burns 1973: 400, 401).

There is also another level of consensus among modern ecclesiastical historians that abuses in the Catholic Church were not the primary religious cause of the Protestant revolution. Some historians are of the view that the reformers were against late medieval theology, which had elaborate sacramental theory, and its belief in good works as a supplement to faith and the doctrine of divine authority conferred on the priest. Christianity in the later middle ages underwent many significant changes and developments from its early medieval character, such that it almost appeared as a new religion. Theological formulations of St. Augustine and Gregory the Great were either modified or expunged. The theological and doctrinal revolution which started in 1050 was carried into the thirteenth century under the influence of St. Thomas Aquinas, St. Francis, and Innocent III.

Christianity of the early middle ages was fatalistic, pessimistic and theoretically opposed to worldliness. Human beings were thought to be inherently wicked and incapable of any good works, independent of God. By the thirteenth century, new ideas emerged. "Life in this world was now held to be exceedingly important, not only as a preparation for eternity but for its own sake as well. No longer was human nature regarded as totally evil. Man could therefore cooperate with God in achieving the salvation of his soul" (Burns 1973:310). Summa Theologica of St. Thomas Aquinas became the guiding theological document for late medieval Christianity. There were numerous pronouncements issued by church councils, especially the Fourth Lateran Council of 1215. The church adopted a new theory of the priesthood, which held that the priest by virtue of his ordination by a bishop and the latter's confirmation by the pope, has become the inheritor of a portion of the authority conferred by Jesus upon St. Peter. The idea was that the priest now had the power to cooperate with God in the performance of certain miracles and in pronouncing forgiveness on sinners from reaping the earthly consequences of their evil deeds.

By the end of the twelfth century, ecclesiological engineering in the medieval church had reached the zenith with the adoption of seven sacraments- baptism, confirmation, penance, marriage, ordination, extreme unction and the Eucharist. Sacraments in the Roman Catholic Church are instruments whereby divine grace is communicated to men. The church in the last centuries of the middle ages accepted and adopted new sacramental theories. It was the view of late medieval church that the sacraments were indispensable avenues for procurement of God's grace, and that there could be no salvation without the sacraments.

Sacraments were considered to be automatic in their effect that is, the efficacy of the sacraments did not depend upon the spiritual, or moral decency of the priest who administered them. The implication is that even though the priest might be unworthy that does not affect the purity and efficacy of the sacrament. The doctrine of transubstantiation was also integrated into sacramental theory at the Fourth Lateran Council: "This doctrine means that the priest, at a given moment in the Eucharistic ceremony, actually cooperates with God in the performance of a miracle whereby the bread and wine of the sacrament are changed, or transubstantiated into the body and blood of Christ" (Burns 1973:311).

The adoption of the theory of the priesthood and the theory of the sacraments increased the power of the clergy and strengthened the formal and mechanical elements in the Latin Church. There was also the growth of humanizing spirit. The humanizing dimension of late medieval Christianity had full expression in the revolt against the selfish asceticism of monks and hermits, in the naturalism of St. Francis and also in the veneration of saints and the Virgin Mary. Since God and Christ were remote and sublime beings, it was wrong to bother them with minor problems. On the other hand, the saints were human, who could be approached for favors instead of disturbing God all the time with petty problems. It was believed that a woman could pray and ask St. Agnes to help her find a husband. Fundamental spiritual significance was attached to reverence for the Virgin Mary.

Burns posits that devotion to Mary as the beautiful and compassionate Mother became the strongest expressions of the humanizing tendency. Mary was venerated both as the ideal woman and also as our Lady of Sorrows: "The grief that she experienced over the tragic death of the son was believed to endow her with a special sympathy for the sorrows of mankind. Though revered as the Queen of Heaven, she was, above all, the goddess of this life" (1973: 312). There was also massive criticism against changes in the organization of the church in the later middle ages. In 1059, a Papal Electoral College called the College of Cardinals was 
constituted. Before that time, members of Papal Electoral College were the deacons, priests, and bishops of certain churches in Rome. With time high ranking clergymen selected from all the parishes of the Western world were appointed into the college, with majority of Italians until 1946. Before 1059, popes were elected by the clergy of the diocese of Rome, and later by powerful nobles and at some times by German emperors. The vesting of the sole right of election in the College of Cardinals led to widespread protest to free the church from undue and excessive political control.

Late medieval Christianity also witnessed the growth and elongation of papal monarchy. The first pope who successfully expanded his supremacy was Nicholas I (1858-1867). While mediating in the disputes between bishops and archbishops, he compelled all of them to submit to his own direct authority. Nicholas was succeeded by series of weak popes; it was only in the pontificate of Gregory VII (1073-1085) that papal monarchy was revived with vigor. The peak of papal monarchy was the pontificate of Innocent III (1198 -1216). In the later centuries of the middle ages, the church adopted new methods of discipline which represented a systematic attempt to extend its moral authority over all the members. Excommunication and the requirement of oral confession became potent channels for the expansion of the authority of the priest. Excommunication was a new idea that did not exist before the eleventh century. The effect of excommunication was to expel a member from the church and to deprive him all the privileges and rights of membership.

At death the body of the excommunicated could not be buried in consecrated cemetery, and within the period of the excommunication, the soul of the person is temporarily confined in hell. Christians were warned not to interact with such a person, otherwise, they may share his fate. A decree of excommunication against a powerful king or noble was followed by an interdict upon his domain. By withholding most of the benefits of Christianity from a ruler's subjects, the church was indirectly instigating resentment against the king which may force him to submit to the church. The Fourth Lateran Council decreed in 1215 that every member is expected to make an oral confession of sins to a priest at least once annually, and also carry out the prescribed punishment before joining in the Eucharist. With this new policy, the authority of the priest as a moral guardian in his parish was consolidated.

The quarrel between King Philip IV of France and Pope Boniface VIII at the beginning of the fourteenth century led to the decline of respect for the papacy. Serious controversies erupted between Boniface and secular authorities. It was the considered opinion of Boniface that the church and priest were subject to no mortal and that the pope had absolute power over everything and everyone on earth (Wallbank, Schrier, Maier and Gutierrez-Smith 1993:388). As a way to checkmate the pride and arrogance of Boniface, King Philip of France (1285-1314), sent armed men to arrest the pope in his palace in Rome. Boniface was later imprisoned, but the people of Rome set him free after few days, Boniface who was in his eighties, died a few weeks later. Thereafter, Philip compelled the new pope to vacate Rome and live in Avignon, France, in 1309.

The papacy was at Avignon for 65 years, it became very unpopular and corrupt. During that time, popes were also seen as puppet of the French kings. In 1378, there was a concerted effort to return the papacy to Rome. This was objected and resisted by France. Italian cardinals elected an Italian Pope, who resided at Rome. French cardinals chose a French Pope, who remained at Avignon. Wallbank, Schrier, Maier and GutierrezSmith (1993:388) writes: "Each pope claimed to be the only true head of the church. Each enjoyed the support of several European rulers, but many faithful believers in Christianity held them in contempt. The dispute finally ended when the Holy Roman Emperor intervened and demanded the election of one single pope in 1417". Papal capital remained at Avignon for nearly seventy years. The religious implication for this new development was captured vividly by Burns (1973:403) : "Surrounded by French influences, the popes who reigned at Avignon were unable to escape the charge of subservience to French interests. In the minds of many Christians the papacy had ceased to be an international institution and had been degraded into the mere plaything of a secular power".

In 1378, the struggle to return the papal capital to Rome, led to the election of two rival popes, one at Avignon and one at Rome, each proclaiming himself as the genuine successor to St. Peter. The division of the church into two factions is known as the Great Schism. Even though the impasse was resolved at the Council of Constance in 1417, it successfully weakened the papacy reasonably before the Protestant revolution. Another factor which hastened the Protestant Reformation was the proliferation of mysticism in the early church. For more than two centuries, mysticism dominated the religious life of northern Europe. The vast majority of mystics were Germans. The mystics were opposed to the rituals of salvation which the medieval church endorsed. It was the collective opinion of the mystics that spirituality could be attained through eradication of selfishness and total surrender to God, which according to them does not require the sacraments, or priestly services.

\section{Social and Political Causes of the Reformation}

We have attributed the clash between the crown and the papacy in the fifteenth century to patriotic feelings and the desire of secular authorities to control the church in their domains. The ability of the Vatican to 
crush the Reformation was weakened through continental political alliance. England was the first country to assert a distinct ecclesiastical independence. From the time of William the Conqueror (1066), the king of England had been the head of the English Church. By the time of the Reformation, France was yet to recover from the impact of the hundred years' war (1338-1453), which frustrated the French nobility and increased the power of the king. Charles VIII (1483-1498), had a desire to make France the headquarters of the Holy Roman Empire, instead of Germany. Pope Leo X and Francis I had in 1516 designed the concordat of Bologna, which conferred headship of the Church in France to the king.

Europe of the Reformation era was propelled by power politics. Religion was generally considered 'spiritless', anachronistic and debased. The spirit of patriotism and national consciousness reached the peak with the evolution of nation-states. There was a clarion call for indigenization of religious culture and devolution of ecclesiastical authority. Such radical demands resulted in insurrection against the Holy See. In the words of N.S.S. Iwe (1979:22), "Rulers were prepared to adopt any religious and ecclesiastical measures capable of ministering to their secular programmes, ambition and greed. Moreover, they were not in the mood to accept any external, or foreign over-lordship in their territories".

Spain before the Reformation was under Islamic government for several centuries, until 1492 when the Moors were expelled from the land. The marriage of Ferdinand of Aragon and Isabella of Castile, paved the way for a new Spanish monarchy that was eager to reform the church and make it subordinate to the king of Spain, which was eventually achieved in 1482 when the king reached an agreement with the Papacy. Germany though unified under the Articles of Confederation, was politically divided into three hundred independent states. From 962, during the reign of Otto the Great, the head of the Germanic states presided over the Holy Roman Empire. Even though the pope was the titular head of the church in Germany, national reforms and consolidation favored a national church under state control.

In Scandinavian countries, the migrations of the ninth and tenth centuries had drained the population. Russia was in the camp of the Greek Orthodox Church, and did not play any active role in the Reformation. Turkey, which became the most powerful Moslem country threatened to conquer the entire Europe and impose Islam as a state religion. Another serious political factor of causation of the Reformation movement was the direct involvement of the church in partisan politics. As the Barbarian pressure led to the fall of the empire, the church assumed political leadership and performed many functions of government. The Gregorian reform movement of the $11^{\text {th }}$ and $12^{\text {th }}$ centuries also had negative consequences. "The churchmen who initiated the reform were resolved not to withdraw from the world, not to collaborate with the world but to dominate the world through the church after she herself had been reformed" (The New Encyclopaedia Britannica 1975 :548). By the end of the $15^{\text {th }}$ century, the Catholic Church had become the largest land holder in Europe. As at that time, half of the land in France and Germany, and two fifths or more in Sweden and England was owned by the church. The church was seen as the richest institution in society and this attracted fierce criticism. The involvement of the church in power politics was a serious problem in sixteenth century Europe. The church usurped the powers of secular authorities and imposed taxes on the masses. Political intoxication and affluence led some popes to assert themselves over kings and emperors. Some popes derailed into unscriptural teachings. Pope Boniface VIII (1294-1303) taught that people who were healthy, rich and lucky were already in paradise. The church also had some problems with the business community in Europe. The merchants of the Italian cities became wealthier, with pronounced interest in material acquisition than in spiritual concerns. The growth of business and commerce also affected the church spiritually and morally. The church criticized lending of money for interest as sinful. It was also painful to some people to discover that some highly placed church leaders were money lenders.

The political climate of the church was also tainted because of the continual contention for supremacy between the bishops of Constantinople and Rome. Until the ninth century, the Eastern or Greek Church was separated from the West in quest of autonomy. In the eleventh century, the pope established universal authority over the church on earth, and assumed despotic power in both ecclesiastical and political issues. The primacy and infallibility of the pope was proclaimed and enforced. Erwin Rudolph (1979: 8) has observed that the Bible was not read personally by the laity, nor well understood by the clergy. Many parishioners practiced immorality. Rome gained notoriety for political intrigue, avarice, homicide, and anything could be bought for a price including the gifts of the Holy Spirit. Norman Cantor (1969:134) holds a very different view on the causation of the Reformation. He attributed the Reformation partly to the deliberate departure of Europe from medieval institutions and ideas. "The reformers not only rejected the medieval structure of church; they looked back to the earliest form of Christianity for their model, seeking in the Scriptures and in the earliest Christian communities pattern of the spirituality to serve as a criterion in their efforts to weed out the evils manifest in the church and in society".

There was no good idea of religious freedom in sixteenth century Europe. The idea of religious tolerance and separation of church and state was unacceptable to many people. It was generally believed that doctrinal truth must be upheld by force, and that individuals had no choice than to accept the infallible and 
inerrant teachings of the church. That was the genesis of the idea of the magisterium-the teaching authority of the church. Cantor $(1969: 134,135)$ has this to say: "The struggle for a true religion demanded the assertion of political power. The Reformation occurred in a period of expanding rationalism, and inevitably it was profoundly influenced by the increasing authority of the nation-states". Four general convocations, or diets were held to reform the church: The first at Pisa, Italy (1409), second at Constance Switzerland (144-18) where John Huss was set ablaze, the third at Sienna Italy (1423); and the fourth at Basel Switzerland (1431) (Rudolph 1979: 9). But the Reformation became inevitable because it was time for change.

\section{Economic Causes of the Reformation}

Economically, medieval Catholic Church was a vast financial empire. The church was rich in furniture, jewels and precious metals which came in as grants by kings and nobles while some came from gifts and bequest of pious citizens. There were also religious restrictions on taxation which exempted Episcopal and monastic property from taxation. This led to a heavier tax burden on the possessions of merchants and bankers and other private owners. At Germany, lesser nobles were threatened with extinction because of the collapse of the manorial economy. Many of them desired church lands to relieve their economic distress.

Resentment against papal taxation was a notable pre-Reformation source of grief and murmuring. The most burdensome papal tax was called Peter's pence, which was an annual levy of one penny on every family. This tax was paid in addition to tithe (one-tenth) of every Christian's income paid for the support of the parish church. Other church sources of income included indulgences, dispensations and appeals of judicial decisions. Burns writes: "In a very real sense the moneys collected for the sale of church offices and annates, or commissions levied on the first year's income of every bishop and priest, were also forms of papal taxation, since the officials... increased collections from the people" (1973:406).

Burns argues that objections against papal taxation was not because it was burdensome and numerous, but that the real basis of grievances was that papal taxation which was seen as a channel for siphoning of wealth from the northern countries for the enrichment and development of Italy. "Economically the situation was almost exactly the same as if the nations of northern Europe had been conquered by the foreign prince and tribute imposed upon them. Some Germans and Englishmen were scandalized also by the fact that most of the money collected was not being spent for religious purposes, but was being squandered by worldly popes to maintain luxurious courts" (Burns 1973:406). The greatest tragedy of medieval Christianity was priestcraft. Instead of being progressive and spiritual, medieval church failed to move with the times and became officially decadent, corrupt and retrogressive. The papacy which claimed apostolic succession failed to provide spiritual leadership. With parishes, monasteries, and convents all over Europe, the cost of maintenance became an acute problem.

Will Durant in his A History of Civilization mentioned the various means employed for revenue generation. It was mandatory according to Durant for every ecclesiastical appointee to remit to the Papal Curia half of their income for the first year, followed by yearly payment of tithe. It was also mandatory for a new archbishop to pay the pope a substantial sum for the pallium- a band of white wool that served as the confirmation and insignia of his authority. "On the death of any cardinal, archbishop, bishop, or abbot, his personal possessions reverted to the papacy... Every judgment or favor obtained from the Curia expected a gift in acknowledgement, and the judgment was sometimes dictated by the gift" (qtd. in Watchtower's Mankind's Search for God 1990:307). In a shameless manner, the medieval church monetized all religious services which the priest rendered to the congregation. A Spaniard of the time is quoted in Mankind's Search for God to have complained: "I see that we can scarcely get anything from Christ's ministers but for money; at baptism money.... At marriage money, for confession money- no, not extreme unction without money. They will ring no bells without money, no burial in the church without money; so that it seemeth that paradise is shut up from them that have no money" (1990:309).

\section{Renaissance and the Reformation}

Another deadly attack on the church came from the Renaissance. The Renaissance, which was characterized by reinvigoration, reanimation and rebirth of intellectual consciousness from apparent death, neglect, obscurity, and depression, catapulted into a colossal nuisance and rebellion against the church. The people of Europe became mentally erratic and excessively possessed by religio-phobia. Everything was subjected to reason and analytic rigor. In the words of George Guest (1979:97): "Man was beginning to think and act for himself, to take an interest in affairs other than fighting and religion. Learning, commerce, and discovery began to attract his attention". This was a period characterized by innovation, creativity, ingenuity and enterprises. Commenting on the impact of Renaissance on Europe, Iwe posited: "It encouraged the spirit of adventure, inquiry and criticism. The Renaissance gave rise to the emergence in Europe of a new generation of humanist scholars and choice spirits... the Renaissance emphasized the values of reason, independence and individualism, secularism and nationalism" (1979:22-23). 
There was a deep-seated and flagrant campaign of calumny against the clerics. This was fueled by the criticism of the humanist scholars like Dean Colet of Oxford, Thomas More, Desiderius Erasmus, Lefevre and Ulrich Von Hutten which actually incited the laity against the clerics. When ideas are logically presented, it has the capacity to captivate the readers' intellect and will power. In the words of Iwe: "The Bourgeoisie in particular nursed violent and incurable jealousy and hatred for the wealth, privileges, prerogatives and benefits of the clergy... This phenomenon of pan-anticlericalism in Europe was one of the root causes of the religious conflict and conflagration known as the Protestant Reformation" (1979:26).

At the root of the Reformation still, was the traditional anti-thesis Italianism versus Germanism culminating in outright and institutional entrenchment of Roman-phobia. The hatred of Rome at a point became chronic, pervasive and bursted into cultural disaffection, rancor and bitterness. The linkage of Roman-phobia with the Reformation has presented an ethnocentric dimension to the causal factors of the Reformation. The Renaissance which was characterized by self-conscious awareness affected the entire world through the manifestation of a new attitude that could be described as individualism.

The implication of individualistic mind-set for medieval Christianity was the infiltration of the new secular spirit into the church. Secularism is preoccupied with the material world instead of eternal, futuristic and spiritual realities. The protracted question before us now is: "Was the Reformation merely the religious aspect of the Renaissance?" Edward Burns has argued persuasively that there were important resemblances as between the two movements and has insisted that both were products of the spirit of individualism which confronted the status quo in fourteenth and fifteenth centuries: "Both partook of the character of a return to original sources: in the one case, to the literary and artistic achievements of the Greeks and Romans; in the other, to the Scriptures and the doctrines of the church fathers" (1973:398).

Burns observed further that even with these similarities of goals; the two movements had different guiding spirit and philosophy. While the essence of the Renaissance was devotion to the human and the natural, religion was relegated to a subordinate position. The spirit and inclination of the reformers tilted to otherworldly dimension and absolute contempt for the present world order (Burns 1973:398). While both the Renaissance and Reformation anticipated the recovery of the golden past, their modus operandi was different. The humanists wanted to revive Greco-Roman antiquity, while the reformers were interested fundamentally in restoring the teachings of St. Paul and St. Augustine in the church. From the foregoing, it is safe to infer that the Reformation was not a part of the Renaissance movement. The Reformation represented a sharp break with the civilization of the later middle ages. Radical reformers rejected the basic theories and practices of thirteenth-century Christianity.

\section{Inconsistent Policy and Clerical Infidelity}

The first administrative lapses that affected the spiritual and moral life of the church were the policy of absolute celibacy. From the fourth century, the church insisted that candidates for the priesthood must accept absolute celibacy. McKay, Hill and Buckler (1987:429) observed that it had always been difficult for the church to enforce total compliance to that policy: "Many priests, especially those ministering to country people, had concubines, and reports of neglect of the rule of celibacy were common. Immorality, of course, included more than sexual transgressions. Clerical drunkenness, gambling, and indulgence in fancy dress were frequent charges". There was also a high level of illiteracy among priests. Many bishops did not consider education of the priest as a priority. Standards for ordination were very low. "Many priests could barely read and write and critics laughed at the illiterate priest mumbling the Latin words to the mass, which he could not understand predictably, this was the disorder that the Christian humanists, with their concern for learning, particularly condemned" (McKay, Hill, and Buckler 1987:429).

Medieval Christianity had the problem of clerical absenteeism and pluralism. Many higher ecclesiastics held offices and parishes, but seldom visited the churches, let alone have the time to perform the spiritual responsibilities which the offices entailed. While the clerics lacked the time to visit the churches, they collected church income from places they have not ministered and miserly paid poor priest a fraction of the income (McKay, Hill and Buckler 1987:429). It is on record that King Henry VIII's chancellor Thomas Wolsey was archbishop of York for fifteen years before his first visit to that diocese. Even though Wolsey had no time to visit the diocese, all the revenues from York were remitted to him. The most notorious example of absenteeism was that of Antoine du Part Archbishop of Sens who entered his cathedral for the first time in his own funeral procession.

Medieval church did not deem it wise to separate the church from the secular powers. Government officials were given high church offices. Church officials also served their monarchs. Bishops and abbots worked for secular governments. Important church men were given political appointments as councilors, diplomats, finance officers, chancellors, viceroys and judges. Another major cause of the Protestant revolution was the reckless display of affluence by high ranking clerics. Prelates lived in magnificent splendor, while the sheepfold wallowed in abject poverty. 
The popes lived like secular Renaissance princes. Pius II (1458-1464), had a reputation as a writer of love stories and Latin poetry. Sixtus IV (1471 - 1484), showed much concern for aesthetics and beautified the city of Rome and funded artistic projects. Innocent VIII (1484 - 1492), gained notoriety for extreme luxury and scandal. The three popes misappropriated the wealth of the papacy to further the material interests of their immediate biological families. The Spanish Pope Rodrigo Borgia, Alexander VI (1492 -1503), publicly admitted his mistress and children. Julius II (1503 - 1513), put up military armor and personally led papal army against the French invaders of Italy in 1506. In the midst of this opulence and squander mania, the parish clergies lived in abject poverty with their members "...the spiritual quality of their lives was not much better than that of the people to whom they ministered. The clergy identified with life; that is, they injected religious symbols and practices into everyday living. Some historians therefore have accused the clergy of vulgarizing religion" (McKay, Hill and Buckler 1987:428).

\section{Demands for Reforms in Medieval Catholicism}

The need for reform of the institutional church and the spiritual renewal of the individual Christian is fundamental to the Christian faith. In the early fifth century, St. Augustine of Hippo described the final stage of world history thus: "In the sixth age of the world our reformation becomes manifest, in newness of mind, according to the image of Him who created us" (qtd. in McKay, Hill and Buckler 1987:428). Saint Bernard of Clairvaux is reported to have complained about the church in the middle of the twelve century: "There is as much difference between us and the men of the primitive church as there is between muck and gold" (qtd. in McKay, Hill and Buckler 1987:428). Christian humanists of late fifteenth and early sixteenth centuries like More, Erasmus, Colet, and Lefevre d'Etaples' all advocated for reforms on the pattern of the early church.

Of all the Christian humanists, we shall single out Desiderius Erasmus for a detailed analysis on his advocacy for reforms in medieval Christianity. Erasmus was a Dutchman by birth. Growing up with the stigma of an illegitimate birth, Erasmus attended monastic schools and was ordained in 1492. He later studied classical literature at the University of Paris. His greatest ambition as a scholar and as a Christian was to help the church. Erasmus believed that the two arch-enemies of Christianity were paganism and tradition. He condemned visits to the grave of saints, mere repetition of prayers. Erasmus was worried about the carelessness of the church in allowing the simple teachings of Christ to encapsulate in myriads of theological dogmas. Erasmus criticized the weakness of monks and theologians who thought that religion consisted in pilgrimages, the worship of relics and the procuring of indulgences.

When Luther started the protest, Erasmus gave full support. As Luther became more strident, and comprehensively confrontational, Erasmus began to distance himself from Luther. As a good church man, Erasmus was of the opinion that rebellion against the pope and the church would produce a devastating effect. Instead of revolt, he preferred to trust in the progressive effects of education and intellectual development. Erasmus concluded that superstitions and undue regard for ceremonial aspects of religion would be outgrown as mankind became more developed and cultivated. Erasmus criticized Luther's rebellion against the pope. Like Luther, Erasmus wanted reforms, but not at the expense of unity. He defended Luther's freedom to criticize abuses, but rejected Luther's militant courage in revolting against established authority. Many reformers faulted Erasmus of vacillation and timidity. As a punishment for his initial support of Luther, some popes put a number of his works on the index of forbidden books.

In Spain, Cardinal Jimenez visited monasteries and pleaded with monks and friars to be dedicated to God, and to set high standards for the training of diocesan priests. Lefevre d'Etaples in France and Colet in England called for a return to the austere Christianity of the early church. In Holland, starting from the late fourteenth century, a group of dedicated Christians called the "Brethren of the Common Life, lived in stark simplicity while daily carrying out the gospel teaching of feeding the hungry, clothing the naked and visiting the sick" (McKay, Hill and Buckler 1987:430). The Brethren visited schools and taught the Bible with the goal of preparing devout candidates for the priesthood and monastic life. The Brethren intended that through prayer, meditation and conscientious application of the Scriptures that Christian ideals would become an inner experience.

In Italy, a group of priests called the Oratories of Divine Love labored to revive the church through prayer and spiritual exegesis of the Scriptures. The members of this group did not withdraw from the world, but devoted themselves to pastoral and charitable activities like founding of hospitals and orphanages. From the French monastery of Cluny, a new and vibrant reform movement emerged with the name the Cluny movement, or the Cluniac revival. The predetermined objective of this movement was to reform monasticism. The Benedictine monasteries, which were the only one in existence by the tenth century in Western Europe, suddenly became corrupt and condoned the leadership and control of feudal nobles.

Cluniac leaders were very desperate to enforce the rules of piety and chastity on the monks and also wanted to liberate the monasteries from feudal domination. By the eleventh century, the Cluniac arrived at a broader vision and mission to eliminate corruption and worldliness from the entire church, abolish all forms of 
feudal control over the secular clergy and over monks, and to consolidate the absolute supremacy of the pope in church matters. Burns writes: "They centered their attacks, first of all, upon simony, which was interpreted to include the buying and selling of church offices, any form of appointment to church offices contrary to the canon law, and the investing of bishops and abbots with the symbols of their spiritual power by secular authorities" (1973:313). The revolutionary nature of the movement led to a change of name, the New Cluny movement. The movement faced powerful and bitter opposition, but most of their programs were implemented by zealous leaders like Hildebrand (the "holy Satan") who became Pope Gregory VII in 1073. Unfortunately, the Cluniac monks degenerated to the same morass of worldliness which they criticized their older Benedictine brothers. The failure of the Cluniac revival in the middle of the eleventh century led to the launching of new movements to set higher and stronger standard of purity, austerity and inner spirituality.

In 1084, the Carthusian emerged with rigorous rules to purify the priesthood. Carthusian monks lived in cells, fasted three days each week on bread and water, wove hair shirts, exhausted all their time in intensive and rigorous prayer, meditation and manual labor. The next movement was the Cistercian order which was established at Citeaux in Burgundy. Within a short time Cistercian monasteries increased to 300 scattered across Western Europe. Perhaps, the most significant reform movement in medieval Christianity was the rise of the Friars in the thirteenth century founded by St. Francis of Assisi (1182 - 1226). Francis was the son of the rich merchant, who felt disappointed with the social values of his people and opted to work toward poverty alleviation through selfless services to the poor. Commenting on the lifestyle of Young Francis, Burns has this to say: "Giving away all of his property and donning the rags of a beggar, he set out on his great mission of preaching salvation in the darkest corners of the Italian cities and ministering to the needs of helpless outcasts" $(1973: 314)$.

The Franciscan Friar's Order which he founded was not members of the clergy, but laymen. Instead of recluse confinement, the Friars devoted their time and energy to social welfare work. The Friar's were determined to apply Christian remedies to social problems. Members of society came to the understanding that the main business of Christianity was not solitary confinement in a monastery or nunnery, but service to humanities. The next order which carried out strict spiritual reforms was the Dominican Order, founded about 1215 by St. Dominic. The primary assignment of this order was to combat heresy. The Dominican Friars adopted the rule of Augustine, but in their piety they were the heirs of the Cistercian Order. The Dominican were critical of the pomp and pageantry which the priest displayed, and opted for a simpler and more apostolic lifestyle. The vita apostolica originated from the Augustinian Order, R. W. Southern (1970:208) comment on the mission of the Dominican Order: "It aimed at combating heresy through preaching reinforced by a primitive simplicity of apostolic life". The Dominicans expected to achieve their goals through education. Even though they had no resources, little learning and almost no books, they were poised to reform Christianity spiritually.

\section{The Papacy as a Monarchy in Medieval Europe}

Medieval Catholic Church was in theory, a universal organization. Politically, the Holy Roman Empire proclaimed its own universality and ignored local and dynastic particularism. The Holy Roman Empire was in reality either German, or Italian in its policy and in administrative focus. With the rise of the monarchy in France and England and in other parts of Europe there was serious resistance to papal claim to universal authority. Norman Cantor writes on the conflict in Europe that bothered on the limits of the authority of the pope over secular matters: "The papacy, as a kind of universal monarchy, thus took on a dual aspect: on the one hand, the popes were rulers of the Papal States and had national and dynastic interests. On the other hand, the church had property in every part of Europe, and as head of the church, the pope claimed authority over that property" (1969:28).

The Roman Curia was unwilling to condone any compromise. Papal authority as the spiritual leader of Europe must be accepted and recognized by all kings if they were to remain in office. Loyalty of kings to the pope was unconditional. The secular rulers had the choice either to respect and recognize the spiritual and political authority of the pope, or face excommunication. Cantor avers that the papacy became so powerful in the thirteenth century to the extent that the authority of the pope became exceedingly sacrosanct: "Having defeated the last of the Hohenstaufens, the popes had nothing to fear from the Holy Roman emperor. Popes like Innocent III and Innocent IV voiced papal claims in extreme terms and behaved like the most powerful sovereigns in Europe" (1969:29). In the fourteenth and fifteenth centuries, with the growth of nation-states, the power of the papacy was comprehensively checked and restricted to spiritual matters. The power of the papacy was the first casualty in the growth of national monarchies and the development of secular culture. Cantor observes that it was no longer possible for the pope to intervene in the ecclesiastical affairs of European states. "The papacy and the College of Cardinals remained preoccupied with Italian politics and dynastic struggles while growing nationalistic feeling added fuel to the fires of religious discontent in northern Europe" (1969:33). 


\section{Heresies in Medieval Catholicism}

In medieval Catholicism, heresy was defined as deliberate doctrinal deviation from the official teachings of the church. Heresy in that sense does not connote error, or untruth. It only means going contrary, or challenging the teaching authority of the church with an opposite, or alternative view. In medieval Catholic Church, many people summed up courage and challenged the pope with uncanonical arguments, which found a ready audience, not only among the urban bourgeoisie, but also among nobles and peasants.

Among those who opposed the corruption in the church was the Italian religious and political reformer, Girolamo Savonarola (1452-98). As a Dominican prior in Florence he preached against contemporary sinfulness and moral corruption in the church. He was excommunicated in 1497 and was hanged and burned as a heretic (Collins English Dictionary 1979:1299). In England, Oxford professor John Wycliffe opened up doctrinal argument with the Roman Curia. Wycliffe condemned the priesthood for its corruption and criticized the Catholic Church for holding unscriptural views on the sacraments. Wycliffe told the medieval church for the first time that the ultimate authority in religious matters was not the pope but the Bible. In his De Veritate Sacree Scripturae (The Truth of Sacred Scripture), Wycliffe posited that "Scripture proceeds from the mouth of God" (qtd. in New Dictionary of Theology 1988:733).

Wycliffe contended authoritatively that the Scripture is superior in authority to the pope, the church and the teaching of the church fathers. He insisted that the priest was not necessary in administration of the Eucharist. He categorically rejected the medieval doctrine of transubstantiation and averred in De Eucharistia (The Eucharist) that the body of Christ is sacramentally concealed in the elements. Wycliffe proceeded further to condemn indulgences and veneration of the saints except Virgin Mary who should be reverenced as the mother of Jesus (New Dictionary of Theology 1988:733). Wycliffe recommended abolition of priestly celibacy. While Czech students from Oxford carried the teachings of Wycliffe to central Europe, John Huss championed the propagation of Wycliffe views in Bohemia. Martin Luther actually acknowledged his deep indebtedness and inspiration to the Bohemian martyr. The followers of Wycliffe (the Lollards) spread the message and encouraged the reading of the Bible by the laity. Christianity was presented as a personal experience based on the Bible. It was the inspiration which the Lollard movement bequeathed to society that culminated in the Peasants' Revolt of 1381 which seriously affected the monarchy, the nobility as well as the church.

Another powerful movement of reform and revival in the medieval church was the Hussite movement in Bohemia. The Hussite's adopted the doctrines of Wycliffe and his followers concerning reforms in the church. Activities of the movement led to a national rebellion in Bohemia against Germany. John Huss the founder of the movement was rector of the University of Prague. Medieval Catholic Church condemned Huss as a heretic and summoned him to appear before the Council of Constance. Huss was guaranteed safety and security during the trial. There was a promise that he may be pardoned, if he would recant. Huss proved intransigent and was burned at the trial venue in 1415. The death of Huss did not terminate the movement. The contemporary Moravian church is the heir of Hussite movement. Cantor observes that: "Although the church, with the help of the German nobility, was able to subdue the Hussites, repression of demands for reform offered no lasting solutions" (1969:33)

\section{Conclusion}

The aim of this study was to discover and interpret the causation of the Protestant Reformation. We have carried out a meticulous content analysis to discover the immediate cause of the Reformation. We have also established the fact that there was background of agitation and protest which fuelled the immediate cause. The study has unveiled the dramatis personae, the protagonists and the moving spirit of the conflict, whose personalities and strengths stimulated and determined the outcome of the struggle. The study has also analyzed the social and political climate in pre-Reformation Europe, and then reached a painful, but inescapable conclusion that the conflict was inevitable. Economic and commercial motivations played a pivotal role in shaping the focus of historical development within the period. The profit motive, the drive for wealth acquisition and institutional exploitation of the poor masses catapulted the Reformation into a social movement and a struggle for social justice.

It is not possible to conclude studies on the causation of the Reformation without a judgmental disposition. The focus here is the apparent institutional weakness and the leadership vacuum at the Vatican- that is, the failure of Pope Clement VII to rise up to the greatest challenge in ecclesiastical history. It is the thesis of this study that world history could have taken a different and positive turn if the Vatican leadership was competent, magnanimous and resolute. The lesson of history will continue to elude us if facts are twisted to satisfy denominational loyalty. It does not make any sense for the causation of the Reformation to be based on denominational logic. The great mistake has already taken place. The whole world is suffering the pervasive and protracted impact of that mistake.

Christianity since then has remained weak and divisive. North Africa which Islam conquered and expelled Christianity till today is completely under Islamic and Arab control. Reformation has emasculated 
Christianity. The church has failed to put into practice the prayers of Jesus "that they may be one" (John 17:11, NIV 1640). Dialogue and ecumenism has been relegated to the domain of rhetoric. The chasm between Catholics and Protestants is widening by the day. The last word is yet to be said on the causation of the Reformation. When causes are traced to the very foundation, there is a never-ending sequence, which will necessitate the cutting of the strands of causation. E. P. Cheney (1927:11) in his Law in History and Other Essays posited that "actual origins eludes us; everything is the outcome of something preceding... the immediate, sudden appearance of something, its creation by an individual, or a group at some one moment of time is unknown in history".

\section{References}

[1]. Allen, J. (trans.) (1930). John Calvin: The Institutes of the Christian Religion, Philadelphia: Westminster.

[2]. Atkinson, C. J. (1988) "Martin Luther" in New Dictionary of Theology, (eds.) Sinclair B. Ferguson, David F. Wright and J. I. Packer, Downers Grove, Illinois: Inter-Varsity, 401404.

[3]. Austin, Bill R. (1987). Austin's Topical History of Christianity, Wheaton, Illinois: Tyndale.

[4]. Bainton, R. (1958). The Travail of Religious Liberty, New York: Harper

[5]. Burns, Edward Mcnall (1973). Western Civilizations: Their Culture, Vol. 1. $8^{\text {th }}$ ed.; New York: Norton

[6]. Cheney, E. P. (1927). Law in History and Other Essays, New York: Macmillan.

[7]. Cantor, Norman F. (1969). Western Civilization: Its Genesis and Destiny, Glenview, Illinois: Foresman.

[8]. Collins English Dictionary (1979). London: William Collins.

[9]. Concordia Self-Study Bible (NIV) (1973).

[10]. Fisher, H. A. L. (1935). A History of Europe, Vol. 1: London: Collins.

[11]. Glonzalez, Justo (1985). The Story of Christianity, San Francis: Collins.

[12]. Guest, George (1979). The March of Civilization, Ibadan: Spectrum.

[13]. Gustavson, Carl G. (1955). A Preface to History, New York: McGraw-Hill.

[14]. Harbison, E. H. (1963). The Age of Reformation. Ithaca, New York: Cornell University Press.

[15]. Iwe, N. S. S. (1979). Christianity, Culture and Colonialism, Port Harcourt: COE.

[16]. Jones, R. T (1988). “John Wyclif” in New Dictionary of Theology, Sinclair B. Ferguson, David F. Wright and J. I. Parker (eds.). Downers Grove, Illinois: Inter-Varsity Press.

[17]. Luther, Martin (1947). Three Treatises, Philadelphia: Muhlenberg.

[18]. Mankind's Search for God (1990). Brooklyn, New York: Watch Tower.

[19]. McNeil, John T (ed.), (1960). Calvin: Institutes of the Christian Religion, II, LCC, Vol. XXI, (trans) Ford L Battles, Philadelphia: Westminster.

[20]. McKay, John P, Bennett Hill and John Buckler (1987). A History of Western Society $3^{\text {rd }}$ edition, vol.1: Boston, Massachusetts: Miffllin.

[21]. "Protestantism". The New Encyclopaedia Britannica, Macropaedia Vol. 15, Chicago: Encyclopaedia Britannica. 1975, 99-108.

[22]. "Reformation". The New Encyclopaedia Britannica, Macropaedia; Vol.15, Chicago: Encyclopaedia Britannica. 1975, $547-557$.

[23]. Robinson, J. H. Medieval and Modern Times, New York: Columbia UP, n.d.

[24]. Rudolph, Erwin Paul (1979). The Martin Luther Treasury, Wheaton, Illinois. Victor.

[25]. Southern, R. W. (1970). Western Society and the Church in the Middle Ages. Harmondsworth, Middlesex: Penguin.

[26]. Wallbank, T. W., Arnold Schrier, Donna Maier and Patricia Gutierrez-Smith (1993). History and Life, 4" edition, Glenview, Illinois: Scott, Foresman.

[27]. Williams, C. P. (1988) "Protestantism" in. New Dictionary of Theology, Sinclair B. Ferguson, David F. Wright and J. I. Parker (eds.).

[28]. Downers Grove, Illinois: Inter-Varsity Press 